\title{
Lateral Column Lengthening as a Single or Combined Procedure in Flexible Flatfoot
}

\author{
AMR GALAL, M.Sc.; GAMAL AL-ADL, M.D. and WAEL AL-ADL, M.D. \\ The Department of Orthopaedic Surgery, Faculty of Medicine, Mansoura University, Egypt
}

\begin{abstract}
Background: Lateral column lengthening is currently the most attractive procedure to correct the deformity. In this study we aimed to evaluate the effect of lateral column lengthening as a single or combined procedure on the clinical and radiological outcome of symptomatic patients with flexible flatfoot.
\end{abstract}

Aim of Study: This study aims was to evaluate the effect of lateral column lengthening as a single or combined procedure on the clinical and radiological outcome of symptomatic patients with flexible flatfoot. Prospective study.

Patients and Methods: 24 pediatric patients with symptomatic flexible flatfoot.

Post-operative evaluation was done via AOFAS Anklehindfoot Scale.

Results: There were significant improvements of the radiological alignment angles post-operatively. Also asignificant improvement of AOFAS score after 3 months postoperatively and the end of follow-up is noticed. Concerning complications, persistent pain (8.4\%), delayed union (8.4\%), graft site hematoma $(4.2 \%)$, partial graft extrusion $(4.2 \%)$ and wound dehiscence $(4.2 \%)$.

Conclusion: Lateral column lengthening in treatment of pediatric flexible flatfoot has a good clinical and radiological outcome. It is associated with few or minor post-operative complications.

Key Words: Flatfoot-Osteotomies - Arthroereisis - Arthrodesis.

\section{Introduction}

FLATFOOT is a commonly observed among children. In spite of being often idiopathic, it might be related to neuromuscular disorders, tarsal coalitions, as well as accessory navicular syndrome [1]. The most common etiology of a flexible flatfeet or pesplanus is ligamentous laxity. Several children below two years are observed due to parental

Correspondence to: Dr. Amr Galal, The Department of Orthopaedic Surgery, Faculty of Medicine,

Mansoura University, Egypt concern about flatfeet. As long as there is flexibility, the majority of children will develop an arch over time [2].

The patient should be evaluated in sitting and standing positions. Flatfoot might be dynamic which necessitates weight bearing during examination to appear. Patients should be examined while walking barefoot for evaluation of both instability and asymmetry of gait. In addition, it is essential observe the shoes for identification of asymmetry of wear of soles. When child is weight bearing, the examiner must evaluate the existence (or nonexistence) of medial longitudinal arch, navicular prominence, abduction of midfoot (too-many-toes sign) as well as heel alignment. The child often presents with a hindfoot valgus. Heel rises and calcaneus manipulation could be valuable for confirmation of flexibility or rigidity of deformity [3].

The most frequently utilized radiograph is Meary's angle: An angle produced by a line through long axis of talus and navicular in relation to the $1^{\text {st }}$ metatarsal axis. A flatfoot has a negative Meary's angle. On lateral view, physician could measure lateral talocalcaneal angle, talometatarsal angle, and calcaneal pitch. On AP foot view, physician could evaluate talometatarsal angle and talonavicular coverage angle [3].

The most significant challenge for a surgeon is to discriminate a condition whichmight have a benign natural history from those whichmightresult in disability if left not treated. The correction of flatfoot deformity could be non-surgical or surgical. Surgical procedurescould be divided into 3 categories: Soft tissue, bony (osteotomies and arthrodesis), as well asarthroereisis [4].

In flexible flatfoot with no symptoms, education and reassurance of parents are essential. Although 
flatfoot might resolve with growth and that there is no evidence that flatfeet cause pain in adult life, parents and children usually seek treatment. Children with spastic or flaccid flatfoot deformity are treated according to symptoms, and existence/ nonexistence of intact protective sensation. Non ambulatory children are usually asymptomatic and treated with no orthoses. Parents have to pay attention for pressure sores if orthoses are used. Ambulatory children complaining of painful sensation related to spastic flatfeet can benefit antispastic drugs and surgery [5].

Surgery is not recommended for children with no symptoms. In symptomatic children, surgery might be indicated after failure of 6 months conservative treatment. Surgical techniques include: Osteotomies Arthroereisis Arthrodesis [6].

\section{Patients and Methods}

\section{Study design:}

This prospective study was conducted at Pediatric Orthopedic Unit, Mansoura University Hospitals in the period from 2017 to 2018.

\section{Patient sample:}

Twenty four $(n=24)$ pediatric patients with symptomatic flexible flatfoot.

\section{Inclusion criteria:}

1- The age of the patients not less than six years.

2- Non paralytic flexible flatfoot.

3- Those with failed conservative treatment or unable to modify the activities that increase pain.

Exclusion criteria:

1- Asymptomatic flexible flatfoot.

2- Symptomatic flexible flatfoot without trial of conservative treatment.

3- Rigid flat foot (tarsal coalition or spasmodic type).

4- Flexible flatfoot below six years.

Paralytic flexible flatfoot.

\section{Patient consent:}

A written formal consent was obtained from all cases after explaining the details of the surgical procedure as well as any possible complications.

\section{Patient preparation:}

Clinical and radiological evaluation as weight bearing anteropsterior view of foot and ankle, weight bearing lateral view of foot, ankle. RI: To assess; Talis posterior dysfunction and Subtalararthritis and CT: To exclude tarsal coalition.

Procedure: Evans calcaneal osteotomy was done anallogeneic, trapizoidal tri-cortical iliac crest graft wedge was situated in distracted osteotomy. Medial soft tissue reconstruction was achieved just underneath tuberosity of navicular and extended to ${ }^{\mathrm{st}}$ metatarsal cuneiform joint. Tibialis anterior tendon's distal insertion underwent elevated from underlying bony tissues. Proximal and medial mobilization of medial tendinous slip to navicular exposed surface is performed. The modified Bunnell procedure along with a soft tissue anchor was utilized in order to anchor medial tibialis anterior tendon slip to tibialis posterior tendon. Multiple suturing was applied along spring ligament. When foot was released from supination, arch maintenance must be noticed.

\section{Outcome measures:}

The entire children underwent AOFAS hindfoot/ ankle scoring pre-operatively, three months following the ${ }^{2 n d}$ foot surgical procedure, and at time of maximal follow-up.

\section{Statistical analysis:}

Data reported by the present study were presented as mean and standard deviation or number and percent. Comparison between follow-up parameters was achieved using paired $t$-test or repeated measures ANOVA. All statistical calculations were achieved using SPSS, 25 (IBM, USA). $p$ value less than 0.05 is considered statistically significant.

\section{Results}

As regard clinical data in the studied patients are illustrated in (Table 1).

As regard comparison between pre-operative and post-operative data in the studied patients, there are significant improvement of the radiological alignment angles post-operatively. These data are shown in (Table 2).

Concerning clinical outcome, there are significant improvement of AOFAS score after 3 months post-operatively and the end of follow-up. These data are illustrated in (Table 3).

As regard complications, they included persistent pain $(8.4 \%)$, delayed union $(8.4 \%)$, graft site hematoma $(4.2 \%)$, partial graft extrusion $(4.2 \%)$ and wound dehiscence $(4.2 \%)$. These data are shown in (Table 4). 
Table (1): Clinical data.

\begin{tabular}{|c|c|c|}
\hline & $\mathrm{N}$ & $\%$ \\
\hline \multicolumn{3}{|l|}{ Pain: } \\
\hline No pain & 19 & 79 \\
\hline Mild, occasional & 4 & 16 \\
\hline Moderate, daily & 1 & 4.1 \\
\hline Severe, almost always present & 0 & 0 \\
\hline \multicolumn{3}{|l|}{ Activity: } \\
\hline Normal & 17 & 70.8 \\
\hline Mild reduction & 5 & 20.8 \\
\hline Unable to do heavy work & 2 & 8.4 \\
\hline \multicolumn{3}{|l|}{ Frontal forefoot: } \\
\hline Neutral & 14 & 58.3 \\
\hline Mild supination & 6 & 25.0 \\
\hline Mild pronation & 4 & 16.7 \\
\hline \multicolumn{3}{|l|}{ Transverse forefoot: } \\
\hline Neutral & 14 & 58.3 \\
\hline$<5$ abduction & 10 & 41.7 \\
\hline \multicolumn{3}{|l|}{ Frontal hindfoot: } \\
\hline Neutral & 14 & 58.3 \\
\hline Mild equinus & 8 & 33.3 \\
\hline Significant equinus & 2 & 8.4 \\
\hline \multicolumn{3}{|l|}{ Sagittal hin dfoot: } \\
\hline Neutral & 16 & 66.7 \\
\hline Mild equinus & 8 & 33.3 \\
\hline \multicolumn{3}{|l|}{ Medial longitudinal arch: } \\
\hline Normal & 16 & 66.7 \\
\hline Mild planus & 6 & 25.0 \\
\hline Planus & 2 & 8.3 \\
\hline \multicolumn{3}{|l|}{ Subtalar motion: } \\
\hline Moving & 16 & 66.7 \\
\hline Limited & 6 & 25.0 \\
\hline Rigid & 2 & 8.3 \\
\hline
\end{tabular}

Table (2): Comparison between pre-operative and postoperative data.

\begin{tabular}{lllll}
\hline & \multicolumn{2}{c}{$\begin{array}{c}\text { Pre- } \\
\text { operative }\end{array}$} & $\begin{array}{c}\text { Post- } \\
\text { Perative }\end{array}$ & \multicolumn{2}{c}{$\begin{array}{c}\text { Wilcoxon signed } \\
\text { ranks test }\end{array}$} \\
\cline { 3 - 5 } & & & $\mathrm{Z}$ & \multicolumn{1}{c}{$p$} \\
\hline Lateral view TMT & $32.5 \pm 6.0$ & $1.8 \pm 3.4$ & -4.3 & $<0.001$ \\
Lateral view TH & $40.7 \pm 7.9$ & $16.6 \pm 6.9$ & -4.3 & $<0.001$ \\
Lateral view CP & $4.7 \pm 4.7$ & $18.5 \pm 3.5$ & -4.3 & $<0.001$ \\
AP view TC & $43.3 \pm 5.5$ & $27.2 \pm 7.0$ & -4.3 & $<0.001$ \\
AP view TMT & $17.3 \pm 4.3$ & $1.3 \pm 4.8$ & -4.3 & $<0.001$ \\
AP view TCC & $33.0 \pm 8.1$ & $23.6 \pm 10.4$ & -3.1 & 0.002 \\
\hline
\end{tabular}

Table (3): Assessment of clinical outcome.

\begin{tabular}{llccc}
\hline & \multicolumn{2}{c}{ AOFAS score } & \multicolumn{2}{c}{$\begin{array}{c}\text { Repeated } \\
\text { measures } \\
\text { ANOVA }\end{array}$} \\
\cline { 2 - 5 } & Range & Mean \pm SD & F & $p$ \\
\hline Pre-operative & $58-74$ & $64.9 \pm 5.3$ & 11.1 & 0.003 \\
Post-operative 3 months & $80-90$ & $83.0 \pm 3.2$ & & \\
End of follow-up & $92-100$ & $95.1 \pm 2.8$ & & \\
\hline
\end{tabular}

Table (4): The reported complications in the studied patients.

\begin{tabular}{lll}
\hline & $\mathrm{N}$ & $\%$ \\
\hline Persistent pain & 2 & 8.4 \\
Delayed union & 2 & 8.4 \\
Graft site hematoma & 1 & 4.2 \\
Partial graft extrusion & 1 & 4.2 \\
Wound dehiscence & 1 & 4.2 \\
\hline
\end{tabular}

\section{Discussion}

Flatfeet deformity is frequently encountered by pediatric surgeons and pediatricians. A lack of literature exists on how to define such a deformity. The nonexistence of medial arch with a valgus hindfoot is the hallmark of Flatfoot [7].

Lateral column lengthening has become an acceptable technique for surgical correction of flexible flatfeet [8]. The guiding principle behind lateral column lengthening is to bring forefoot and midfoot out of abduction while using the foot's natural bony architecture to drive hindfoot into inversion and dorsiflexion [9].

In this study, there was statistically significant improvement of radiographic angular measurements. This is in accordance with the study of Viegas [10] who reported the results of reconstruction of flexible planovalgus foot in children by using an Evans calcaneal osteotomy in 16 patients. Their work showed significant improvement of radiographic angular measurements. Similar conclusions were reported by the prospective study of Zeifang, Breusch [11] on 32 patients (46 feet) with spastic flexible flatfoot. Also, Dogan, Albayrak [12] who evaluated the results of calcaneal lengthening using the modified Evans osteotomy technique in 11 patients ( 22 feet) with flexible pes planovalgus found significant improvement of all radiographic angular measurements post-operatively.

In our study, surgical interference resulted in significant clinical improvement after 3 months post-operatively and at the end of post-operative follow-up as assessed by the AOFAS score. These findings are in line with the study of Moraleda, [6] who compared the clinical and radiolgical outcomes of calcaneo-cuboid-cuneiform osteotomies and calcaneal-lengthening osteotomy for symptomatic flexible flatfeet. In their work on 33 feet with a calcaneal-lengthening osteotomy, the operative interference produced in significant improvement of the clinical outcome evaluated by the ACFAS score (flatfoot module). 
In addition, the study of Westberry, Davids [13] on 17 children ( 21 feet) subjected to lateral column lengthening found significant clinical and radiological improvement at the end of follow-up.

In another set of patients, Marengo, Canavese [14] evaluated clinical, functional and radiographic outcomes of calcaneal lengthening osteotomy for correction of symptomatic flatfeet in skeletally immature patients. In order to assess clinical and functional outcome, all patients were evaluated according to AOFAS clinical criteria before surgery and at last follow-up visit. Results revealed that AOFAS score showed significant improvement from a pre-operative mean value of $49.9 \pm 16$ to a post-operative value of $89 \pm 15.9$.

In the present study, the reported complications included persistent pain (8.4\%), delayed union $(8.4 \%)$, graft site hematoma $(4.2 \%)$, partial graft extrusion (4.2\%) and wound dehiscence (4.2\%).

In comparison, the reported complications/ shortcomings in the study of Viegas [10] Viegas (2003) were mild sural neuropathy (17.6\%), physical therapy for general strengthening and overall gait training $(35.3 \%)$ and late midstanceadductory twist $(5.9 \%)$. In the study of Zeifang, [15], five of 32 patients ( 7 of 46 feet) had a recurrence of the deformity post-operatively and nine feet had dorsal subluxation of the distal calcaneal fragment. Other complications included minor wound breakdown and fibrous union of the calcaneal osteotomy [13].

No pain detected in most cases except in those 2 cases with calceno cuboidal subluxation, but with long term follow-up due to effect of LCL on subtalar joint osteonecrosis.

The advantages of LCL are technically easy, with low risk of complications and it can allow other procedures to be applied in the surgery like orthro diseases and it will be technically easy if it is required because the joint will be correctly alignment [4].

\section{Conclusion:}

Lateral column lengthening in treatment of pediatric flexible flatfoot has a good clinical and radiological outcome. It is associated with few or minor post-operative complications.

\section{References}

1- VULCANO E., C. MACCARIO, and M.S. MYERON: How to approach the pediatric flatfoot. World Journal of Orthopedics, 7 (1): p. 1, 2016.
2- SHAPIRO F.: Pediatric Orthopedic Deformities, Volume 2: Developmental Disorders of the Lower Extremity: Hip to Knee to Ankle and Foot: Springer, 2019.

3- KWON J.Y. and M.S. MYERSON: Management of the flexible flat foot in the child: A focus on the use of osteotomies for correction. Foot and ankle clinics, 15 (2): p. 309-22, 2010.

4- MOSCA V.S.: Flexible flatfoot in children and adolescents. Journal of children's orthopaedics, 4 (2): p. 107-21, 2010.

5- FORD S.E. and B.P. SCANNELL: Pediatric flatfoot: Pearls and pitfalls. Foot and ankle clinics, 22 (3): p. 64356, 2017.

6- MORALEDA L., et al.: Comparison of the calcaneocuboid-cuneiform osteotomies and the calcaneal lengthening osteotomy in the surgical treatment of symptomatic flexible flatfoot. Journal of Pediatric Orthopaedics, 32 (8): p. 821-9, 2012.

7- TAHA A.M.S. and D.S. FELDMAN: Painful flexible flatfoot. Foot and ankle clinics, 20 (4): p. 693-704, 2015.

8- BEIMERS L., et al.: CT measurement of range of motion of ankle and subtalar joints following two lateral column lengthening procedures. Foot \& ankle international, 33 (5): p. 386-93, 2012.

9- SANDS A.K. and J.P. TANSEY: Lateral column lengthening. Foot Ankle Clin., 12 (2): p. 301-8, 2007.

10- VIEGAS G.V.: Reconstruction of the pediatric flexible planovalgus foot by using an Evans calcaneal osteotomy and augmentative medial split tibialis anterior tendon transfer. The Journal of foot and ankle surgery, 42 (4): p. 199-207, 2003.

11- ZEIFANG F., S.J. BREUSCH, and L. DÖDERLEIN: Evans calcaneal lengthening procedure for spastic flexible flatfoot in 32 patients (46 feet) with a follow-up of 3 to 9 years. Foot \& ankle international, 27 (7): p. 500-7, 2006.

12- DOGAN A., et al.: The results of calcaneal lengthening osteotomy for the treatment of flexible pes planovalgus and evaluation of alignment of the foot. Acta Orthop. Traumatol. Turc., 40 (5): p. 356-66, 2006.

13- WESTBERRY D., et al.: The operative correction of symptomatic flat foot deformities in children: The relationship between static alignment and dynamic loading. The bone \& joint journal, 95 (5): p. 706-13, 2013.

14- MARENGO L., et al.: Clinical and radiological outcome of calcaneal lengthening osteotomy for flatfoot deformity in skeletally immature patients. European Journal of Orthopaedic Surgery \& Traumatology, 27 (7): p. 989-96, 2017.

15- ZEIFANG, et al.: Evans calcaneal lengthening procedure for spastic flexible flatfoot in 32 patients (46 feet) with a follow-up of 3 to 9 years. Foot $\&$ ankle international, 27 (7): p. 500-7, 2006. 


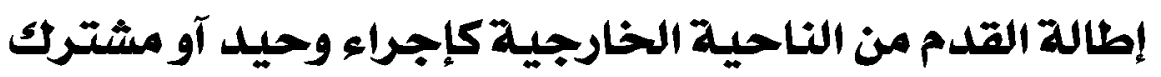

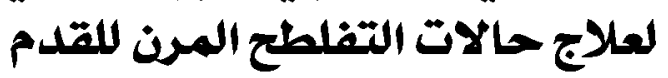

يعد إطالة العمود الجانبى حالياً واحداً من آهم الوبائل الجراحية الآكثر جاذبية لتصحيع التشوه بالقدم والذى يكن مصحوباً بمضاعفات جانبية بسيطة.

الهدف من الدراسهة: تقييم تآثيّر إطالة العمود الجانبى كإجراء واحد آو مجتمعة على النتائج العسريرية والإشعاعية لمرضى الآعراض الذين يعانون من القدم المسطحة المرنة.

المرضى: عץ مريضاً للأطفال يعانون من القدم المسطحة مرنة آعراض. تم إجراء تقييم ما بعد الجراحة عبر مقياس (AOFAS-

(AOFAS ANKLE

النتائج:كان هناك تصسن كيير فى نوايا المحاذاة الإشعاعية بعدد الجراحة. كما وجد تحسن كبير فى درجة AOFAS بعد ثُألاثة آشهر

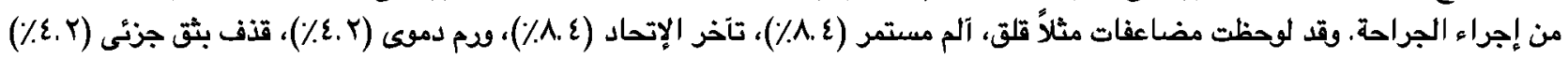
وتفكك في الجرح (Y.\&.).

الإستتاج: إطالة العمول الجانبى فى علاج القدم المسطحة المرنة للآطفال لها نتائج سريرية وإثعاعية جيدة. كما آنه قد يكون مصحوب

ببعض المضاعفات البسيطة. 